\title{
Vaktaalrubriek
}

\section{Meertalige Terminologielys: HIV/VIGS}

\author{
M. Alberts \\ Terminologie-Afdeling, Nasionale Taaldiens, Departement Kuns, Kultuur, Wetenskap en Tegnologic, Pretoria
}

\section{INLEIDING}

Die Terminologic-Afdeling van die Nasionale Taaldicns, Departement van Kuns, Kultuur, Wetenskap en Tegnologie is versock om 'n mecrtalige HIV/VIGS-terminologielys saam te stel as deel van die Departement se bydrae lot HIV/VIGSbewustheid. Verskillende belangegroepe hel saamgewerk om te verseker dat die terminologiclys aan die nodige vereistes voldoen, naamlik om inligting oor HIV/VIGS met behulp van gestandaardiscerde terminologic oor te dra aan tienderjariges (sekondêre skoolvlak) en die algemenc publick.

Die brontaal is Engels en dic docltale is Afrikaans, Sepedi, Sesotho, Setswana, IsiZulu, IsiXhosa, Siswati, isiNdebele, Xitsonga en Tshivenda. Alle brontaalterme is voorsien van baic eenvoudige verklarings in Engels. Termekwivalenle en verklarings word ook in die tien doeltale verskal.

\section{TERMINOLOGIEDOKUMENTERING}

'n Basiese terminologiclys is saamgestel uit ongevecr 350 kernterme wat in HIV/VIGS-onderrig gebruik word. Dic terminologiclys bevat nic ingewikkelde mediese terme nic en konsentreer hoofsaaklik op terme wat in die alledaagse gesprek gebruik word. Die register van die verklarings is so ecnvoudig moontlik gehou.

Dic teikengebruikersgrocp is na breedvoerige gesprekvocring deur dic Terminologie-Aldeling en die Departement van Gesondheid gesamentiik bepaal.

Die Departement van Gesondheid en dic Aids Training, Information and Counselling Centre (ATICC) (VIGS-Oplciding-, Inligting- en Voorligtingsentrum) hel dic Terminologie-Afdeling van boekies en brosjures oor die onderwerp voorsien. Sommige van hierdie publikasies was in Engels sowel as in sommige van die doeltale, namilik Afrikaans, \$epedi, Sesotho, IsiZulu en IsiXhosa, beskikbaar.

Die terminoloê het terme uit hierdic publikasies gec̈kserpecr. Terme is ook van die Internet bekom, en alle brontaalterme is van ecnvoudige verklarings voorsien. ' $n$ Voorlopige termlys is daarna vir goedkeuring aan die Departement van Gesondheid oorhandig.

$\mathrm{Na}$ beraadslaging met die beamptes van die Departement van Gesondheid is die termlys aangepas om dic anbevelings van vakkundiges tc akkommodecr. Die Alrikaanse en Afrikataalterminoloc̈ het begin om vertaalckwivalente en verklarings in dic verskillende doeltale by te werk. Dic voorsiening van doeltaalekwivalente het geskied in noue samewerking met belanghebbendes op dic terrein van onderrig en opleiding. Moedertaalsprekers is ook tydens die vertaling van die verklarings geraadpleeg.

Die konseptermlys is tydens verskeie interne terminologievergaderings bespreck, en die nodige wysigings is op die databasis aangebring. Kopieë van die konseptcrmlys is aan taalkundiges verbonde aan verskeie universiteitc, onder andere UNISA, die Universiteit van Zululand, Fort Hare Universiteit, dic Universiteit van Pretoria, die provinsialc Taalraad van Mpumalanga en die voormalige Staatstaaldiens gestuur vir kommentaar oor die taalkundige korrektheid van die doeltaalterme.

Die terminologiese inligting op die databasis is vervolgens aangepas volgens die kommentaar wat van die vakkundiges en taalkundiges ontvang is. 'n Finale konseptermlys is hierna saamgestel vir toetsing deur die Department van Gesondheid.

Die Departement van Gesondheid het verantwoordelikheid daarvoor aanvaar om 300 kopieë van die konseptermlys te produseer en om die lyste te versprei onder gesondheidswerkers wat veral op die gebied van VIGS werksaam is. Hierdie werkers is deur die Departement van Gesondheid geïdentifisecr as mense wat in staat sou wees om dic aanvaarbaarheid van dic terme in die werksomgewing te tocts. Die doel met hierdic fase was om sovecl insette as moontlik van hierdie werkers te ontvang. 'n Kort behoeftebepalingsvraelys is ook by hierdie konsepdokument ingesluit om bepaalde vrae aan die respondente te rig.

\section{STANDAARDISERING VAN TERMINOI.OGIE}

Hierdie was een van die cerste meertalige projekte, en dic Terminologic-Afdeling moes baic beplan en sell's herbeplan om die projek af te handel. Die finansicring van die verskillende fases van die projek was ook 'n probleem.

In die deliniëringsproses van brontaalterme (Engels) moes verskillende bronne geraadpleeg word om seker te makk dat die konsepte eksak verklaar word. Brontaalterme is met behulp van cenvoudige definisies verklaar. Daar is van 'n gekontrolecrde woordeskat gebruik gemaak om terme mee te verklalar.

Dic konseplys is onlangs by ' $n$ interministeriëlc vergadering voorgelê. Vertecnwoordigers van die Departement van Kuns, Kultuur, Welenskap en Tegnologic hes by dié vergadering voorgestel dat werkwinkels gehou word om die terme en vertalings weereens te bespreek ten einde veral die termekwivalente in die Afrikatale finaal te bespreek, uit te klaar en te standaardisecr.

Dic doel van die eerste werkwinkel was om die brontaalterminligting (register, Engelstalige termkorpus en verklarings) te finaliseer om te verseker dat wysigings wat in die brontaalterminligting aangebring word, deurgevoer kan word na die doeltale voordat die doeltaalterminligting bespreek word. Die werkwinkel is reeds gehou en is deur 'n mediese dokter en ander gesondheidswerkers in die VIGS-veld bygewoon.

Met die tweede werkwinkel word beoog om die doeltalckwivalente en verklarings (Afrikaans en Afrikatale) to finalisecr. Die probleemterme sal deur moedertaalsprekers, wat as gesondheidswerkers in die spesifieke taalgemeenskappe werk. bespreek word om die korrektheid, gepastheid cn aanvalarbaarheid daarvan te verifieer. So 'n proses verseker in 'n groot mate die standaardiscring en gebruikswaarde van dic terme.

\section{TERMINOLOGIE}

\section{I PROBLEEMTERME}

Volgens Alberts (1990: 89) is terme slegs simboliese voorstellings vir bepaalde konsepte wat abstrak en ontdaan van enige 
emotiewe konnotasie behoort te wees. Ondanks die vereiste dat terme slegs konsepte moet denoteer, verkry sekere terme ook emotiewe waardes - veral as hulle tot die gewone omgangstaal deurdring. Die leit dat daar beslis terme is wat 'n gunstige of ongunstige reaksic by gebruikers ontlok, malak dit belangrik dat vakıaalgebruikers bewus moet wees van die emosionele elfek wat sekere terme op die ontvanger van dic hoodskap kan hê. Dit is dus belangrik dat die korrekte lerme gebruik word om 'n bepaalde boodskap oor te dra en dat terme in vakwoordebocke en terminologiclyste so raak moontlik gedefinieer word om meerduidigheid of foutiewe konnotasic te verhoed (Alberts 1990:112-113).

HIV/VIGS is by uitstck ' $n$ domein walarin emoticwe konnotasies aan tcrme geheg word. Dic tockenning van emoticwe waardes aan terme word bepaal deur dic kulturele en ideologiese omstandighede van die sender van dic boodskap, plus dic geassosicerde konnotasies van die moedertaalsprekers van dic besondere brontaal. Dic kultuurgebondenheid van bepaalde terme veroorsaak dat terme nic altyd suksesvol deur verskillende kultuurgroepe vertolk of vertal kan word nic (Alberts 1990: 90).

Dic HIV/VIGS-terminologiclys moes baic neutraal wees om nie aanstoot aan bepaalde groepe te gee nie. Reeds in die doeltaal moes terme van emotiewe komnotasic gestroop wees. Terme soos "AIDS" en "carrier" is van die begin as problematies geidentiliscer.

Die kommentaar op die lys het ook getoon dat respondente die terminologie verskillend benader. Persone wat kommentaar vanuit die Eerstewêreld-perspektief gelewer het, beweer dat die HIV/VIGS-terminologie meer positief word. Dalar word nic meer gepraat van 'n VIGS-Iyer (an AIDS sufferer) nie, MAAR van 'n persoon wat mel HIV leef (a person living with $/ M V$ ). Ander respondente heg egter nie dieselfde konnolasie aan dié terme nic.

Kommentaar is ook ontvang waarin versock is dat prostitusic en sckere seksuele groeperings nic gestigmaliseer moet word nic. Alle terme moes dus baic neul ralal gedelinieer word.

Daar moes desnicteenstaande gesorg word dat die aanslag van die terminologiclys oorecnstem met die aanslag van dic HIV/ VIGS-veldıg van die regering. Slegs dan kan bepalal word hoe daar op die kommentaar gereageer behoort le word.

'Voorbeclde van neutrale definisies:

bisexual n. A person who is sexually attracted to both men and women. [Geen vooroordeel uitgespreek]

carrier Someone who has an inlection and can pass it on to other persons even though he or she may not yet show any symptoms. [Geen verwysing na VIGS]

drug addict Person who is unable to stop taking harmful drugs, cg cocainc. [Geen vooroordeel uitgespreek]

homosexual $n$. (gay) A person sexually attracted to somebody of the same sex, for example a man who is sexually attracted to another man. [Geen vooroordeel uitgespreek]

leshian A woman who is sexually attracted to other women. [Geeu vooroordeel uitgespreek]

prostitute Person who earns moncy by having sex with anyone who will pay for it. [Geen verwysing na risiko vir oordrag van VIGS]

\subsection{VULGÊRE TERME}

Die terminoloë moes kultuurverskille baic delikaat hanteer. Sekere sake mag byvoorbeeld bloot nie genoem word nie. Daar word byvoorbeeld nie oor surangerskep in Alrikatalalgeledere gepratl nie. Terme wal me liggaamsfunksies. genitaliec. enige vorm van geslagsgemeenskap en seksued oordralabare sickles te doen het, is baie eksplisiet. Sodanige terme word as vulgêr beskou en is uiteraard taboc. Eulemismes moes voorsien word om die krasheid van die terme te versag. en vulgere terme moes as sodanig geëtikenter word. Die gebruik van hierdie soont lerme is nie in alle gemeenskappe (stedelik/platlelands; jonk/oud, manlik/vroulik) ewe anvalarbaar nie.

\section{Voorbeclde:}

condom (male condom. CD) <eluphemism> French letter $\langle$ enphemism>, raincoat $\langle e$ uphemism $\rangle$. overall <etuphemism>, sheath <euphemism>. Johnnies <etuphemism>) ...

have sexual intercourse (sleep together <euphemis $m>$...

\subsection{ETIKETTERING}

Etikelte is gebruik om die woordeboekgebruiker gebruiksleiding te gee. Dalar is byvoorbeeld etikette wat aantoon dall 'n beparalde term in onbruik geraak het (Obsolete), 'n versagtingsvorm (Luphemism), geografiese gebruik (US = United States; $G B=$ Great Britain) of handelsname aandui.

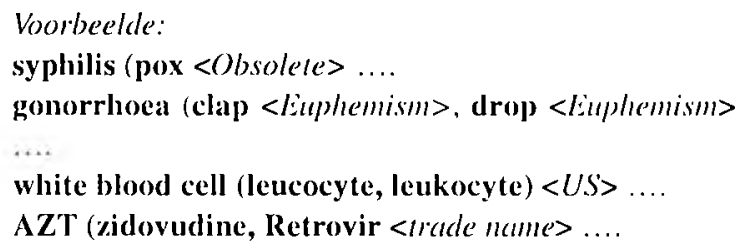

\subsection{REGISTER}

Die register van definiëring is deurgaans baic laag gehou ten einde seker te mak dat die betekenis van die terme duidelik oorkom. Oxford Advanced Leamer's Dictionary. Longman Dictionary of Comtemporary English en Collins Cobuild is as riglyne vir die register gebruik. Verskeie mediese woordebocke is as kontrolebronne gebruik om te verseker dal die verklarings welenskaplik korrek is.

In die brontaal is hoëregisterterme sowel as lacregisterterme opgeneem om eerstens naslaan vir die medicse personecl te vergemaklik, en tweedens dic woordeskal van dic lekegebruikers uit te brei. Dil stel die gesondheidswerkers in staat om mel mekaar en ook met pasiënte te kommunikeer:

\section{Voorbeelde}

chancroid (soft sore) A discase passed on from one person 10 another by having sex with him or her; causes sores, usually on the outer sex organs

haemophiliac (bleeder) A person, usually a man, who suffers from a sickness in which the blood does not clot properly.

white blood cell (leucocyte, leukocyte) $<U S>$ Blood cell that lights against infection.

pyrexia (fever) Higher than normal body temperature which is often a sign of illness.

Voorbeeldmateriaal is slegs in dic brontaal om plek te bespaal 


\subsection{WISSELVORME}

Wisselvorme is as sinonieme opgeneem.

Voorbceldc:

fetus (foetus) The name given to the unborn baby in the womb of a pregnant woman after the lirst 8 wecks of pregnancy

foetus $\Rightarrow$ fetus

\subsection{SINONIEME}

Alle sinonieme het pylverwysings $(\Leftrightarrow)$ na dic volledige inskrywing.

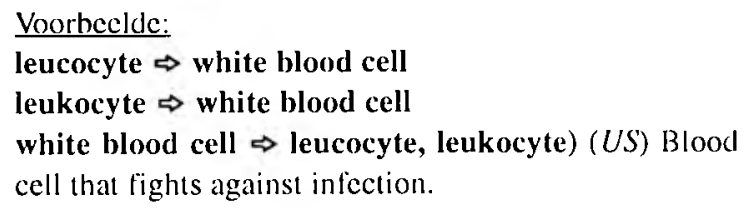

Voorheclde:

leucocyte $\Rightarrow$ white blood cell

leukocyte $\Rightarrow$ white blood cell

white blood cell $\Rightarrow$ leucocyte, leukocyte) (US) Blood cell that fights against infection.

\subsection{AFKORTINGS/AKRONIEME}

Die afkorting of akroniem word op sy cic alfabeticse plek opgeneem, met 'n verwysing na die volledige inskrywing. Alkortings word gewoonlik onder dic volvorm gehanteer (vgl. PHC), behalwe waar die konsep hoofsaaklik in sy alkortingsvorm of as akroniem bekend is en so gebruik word, soos EI.ISA,

\section{AZ'T en AIDS.}

\section{Voorbeclde:}

AZT (zidovudine, Retrovir <trade name> One of the first drugs used to treat people with HIV/AIDS.

zidovudine $\Rightarrow$ AZT

ELISA (enzyme-linked immunosorbent assay) Blood test to find out whether a person has been infected with the virus that causes AIDS (HIV).

enzyme-linked immunosorbent assay $\Rightarrow$ ELISA

$\mathrm{PHC} \Rightarrow$ primary health care

primary health care (PHC) Health care to keep people healthy, discover health problems at an carly stage and prevent discase.

\subsection{DEFINIËRING}

Daar is van 'n gekontroleerde woordeskat gebruik gemaak om tcrme mec te verklaar, wat verseker het dat die terme noodwendig in eenvoudige taal verklaar word. Indien terme noodgedwonge in delinisies gebruik moes word, is hulle ook as lemmas op hul allabetiese plek in die lys cenvoudig verklaar.
Voorbecld:

Gewone woorde is gebruik om dic term gonorrboea te delinicer, en waar daar weliswaar terme in die delinisic voorkom, is elke term op sy beurt op sy allabetiese plek opgenecm en verklaar, vgl.:

gonorrhoea (clap) <euphemism>, drop <euphemism>A discase passed on from one person to another by sexual contact causing a discharge from the sex organs.

discharge n. Fluid coming out of a body opening; can be normal, but can also be the result of an infection.

disease (sickness, illness) Unhealthy state of the body, such as HIV/AIDS' or tuberculosis.

sexual contact Bodily contact connected with sexual activity.

sex organ Outside body part of a man or a woman that has to do with sex, such as the penis and vagina.

\section{PAD VOREN'TOE}

Dic meertalige HIV/VIGS-termlys is in konsepvorm vir kommentaar beskikbaar. Dic Dic Terminologic-Aldeling ontvang graag kommentaar op hierdic lys ten einde registergebruik en terme, termekwivalente en verklarings final tc bespreck en, waar moontlik, te standaardisecr.

Dic tcrminologiclys sal, nadat dit gelinaliseer is, gedruk en versprei word. Dic lys sal egter ook op dic TerminologicAfdeling se tuisblad op dic Internet geplaas word, alangesien dit outomaties decl sal uitmaak van dic Nasionale Termbank. Kundiges, belanghebbendes en belangstellendes sal steeds kommentaar kan lewer. en die terme sal van tyd tot lyd na oorlegpleging met dic nodige vakkundiges en laalkundiges aangepas kan word.

\section{LITERATUURVERWYSING}

Alberts, Mariëta.(1990). '" Bepaling' ran Afrikaanse Vakleksikografiese Behoefies. Pretoria: Unisa. (Ongepublisecrde D.Lill. el Phil.-tesis).

Terminologic-Afdeling, Nasionale Taaldiens. Multilingual AIDS terminology (Konseplys). Pretoria: Departement van Kuns. Kultutr. Wetenskap en Tegnologie.

\section{NAVRAF}

Navrac oor dic HIV/VIGS-terminologiclys kan gerig word aan:

$\begin{array}{lll}\text { Mev. Jeanetla Stcyn of } & \text { Mcv. Christine Marais } \\ \text { (012) } 3378153 & & (012) 3378160 \\ \text { vt17@acts2.pwv.govaa } & \text { pt22@acts2.pwv.go1:-a }\end{array}$

Faksnommer (012) 3254943

Terminologic-Afdeling, Nasionale Taaldiens, Privaat sak X894, Pretoria, 0001 